\title{
Authenticity in Employment Relations A Theology of the Workplace Analysis
}

\author{
Tackney, Charles Thomas
}

\author{
Document Version \\ Final published version
}

Publication date:

2014

\section{License \\ CC BY-NC-ND}

Citation for published version (APA):

Tackney, C. T. (2014). Authenticity in Employment Relations: A Theology of the Workplace Analysis. Paper presented at The Academy of Management Annual Meeting 2014, Philadelphia, United States.

Link to publication in CBS Research Portal

\section{General rights}

Copyright and moral rights for the publications made accessible in the public portal are retained by the authors and/or other copyright owners and it is a condition of accessing publications that users recognise and abide by the legal requirements associated with these rights.

\section{Take down policy}

If you believe that this document breaches copyright please contact us (research.lib@cbs.dk) providing details, and we will remove access to the work immediately and investigate your claim. 


\section{Authenticity in Employment Relations: A Theology of the Workplace Analysis

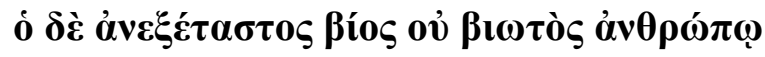

"Life without this sort of examination is not worth living" (Socrates, Apology, 38a)

A Paper Submitted to the Management Spirituality and Religion Division,

Academy of Management Conference, Philadelphia 2014

Charles T. Tackney, Ph.D., Associate Professor

Department of Intercultural Communication and Management

Copenhagen Business School

Porcelænshaven 18A

Frederiksberg, Denmark DK-2000

+45-3815-3815, Tel.

+45-3815-3840, Fax.

ct.ikl@cbs.dk, email 


\begin{abstract}
This research takes up the concept of authenticity as a criterion variable for theology of the workplace analysis, a domain which explores employment parameters in light of religious teaching on the social question at national, organizational or firm-specific levels. Following a review of the concept in Western culture, philosophy, and management studies, Religious Society of Friends (Quaker) and Roman Catholic social teachings are investigated for positively correlative data to help develop the criterion variable. From the literature review of concept and historical data in both traditions, it becomes possible to specify employment relations parameters between the indirect and direct employer and employees in a manner that will ensure working conditions consistent with these traditions, substantially enhancing the prospect of authenticity in employment relations. This theology of the workplace analysis should complement and support corporate social responsibility, management spirituality, authentic leadership / authentic follower, and other secular research by offering a research methods bridge between empirically grounded theology and secular studies, with the common goal of improving workplace and enterprise function for competitive and sustainable enterprise, organization, and national outcomes.
\end{abstract}




\section{Authenticity in Employment Relations: A Theology of the Workplace Analysis}

This paper reviews literature to develop and apply authenticity as the criterion variable for theology of the workplace analysis. The practical and normative good in workplace relations will be indicated by correlatives derived from "the social question" in Roman Catholic and Religious Society of Friends (Quaker) social teaching (RCST/QST). We first review authenticity in Western philosophy, culture, management research, epistemology and theology. Then, authenticity conditions from RCST and QST are derived and discussed.

Authenticity has long been a term of interest in Western history, philosophy, and culture. As these two examples show, it turns up in surprising places, explicitly or implicitly. The U.S. Republican Party (GOP) primary in Wyoming presently finds Liz Cheney in a bitter contest against a GOP colleague and friend of her father, the former Vice-President. Her electoral viability is in question because she mostly grew up out of state. Joseph Milczewski, a state GOP strategist, observed, "Authenticity has always been the biggest attribute you can have in Wyoming. If you don't come across as authentic, these ranchers in Niobrara County and Converse County, they’ll smell it a million miles away" (Sullivan \& Tumulty, 2013). Authenticity is implicitly at issue for Duquesne University. In 2012, this Roman Catholic university sought to prevent adjunct instructor union certification elections on the religious freedom grounds of being a "church-operated school" and, thus, exempt from U.S. labor law (Oppenheimer, 2012). Yet, as RCST offers over a century of unequivocal support for employees' rights to organize and bargain collectively, how can this educational institution claim Roman Catholic authenticity in respect to social teaching when pursuing a legal subterfuge? 
The concept of authenticity is particularly important and empirically useful for employment analysis from both secular and theological perspectives. It may well serve as a correlative, bridging standard, uniting these domains with research on corporate social responsibility and sustainability studies. A theology of the workplace specifies "the institutional and institutionalized features that variously enable or constrain managerial prerogative and employee participation within worksite, firm, organization, sector, region, or national political economy in light of religious doctrine" (Tackney, 2012, p. 106). ${ }^{1}$ Accordingly, this exploration of authenticity as the criterion variable for theology of the workplace research is offered to support and complement the variety of studies being done under Management Spirituality and Religion Division auspices of the Academy of Management. The Division aims at "the study of the relationship and relevance of spirituality and religion in management and organizations" (Management and Spirituality Division, 2013). Specification of a criterion variable for an empirical theology of the workplace will aid theology, advance Divisional methods, and exemplify the 2014 Conference theme: "The Power of Words." Our interest is in the power of one word, authenticity, and it's utility to empirically ground theological investigation of employment relations (Academy of Management Conference, 2013).

The goal of this paper is specification of empirically verifiable employment conditions that ensure or enhance the prospect of authentic employment circumstances as indicated by RCST/QST. This theology of the workplace aims to be "a disciplinary analysis (that) may offer useful guidance in regard to ensuring authenticity in employment relations even, and particularly, in contexts of religious pluralism and secularity" (Tackney, 2012, p. 115). Empirical clarification

\footnotetext{
${ }^{1}$ The path to a theology of the workplace domain analysis comes from comparative reflection on Japan's postwar industrial relations features in employment law (Kettler \& Tackney, 1997; Tackney, 1995). There is also a curious workplace re-evangelization implicit in the export of Japanese management practice to the U.S. in regard to employment protection and participation possibilities (Tackney, 2009a).
} 
of authenticity as a potentially compelling criterion or predictor variable is needed. ${ }^{2}$ Theological studies to date have examined general theories of economics and market, but there is hardly any detailed linkage to labor market conditions or industrial relations research (Cosden, 2004; Finn, 2006; Martin, 2008; Volf, 2001). In a word, theology has a lot of catching up to do. ${ }^{3}$

The labor market has at least three unique features. The first is crucial and insufficiently appreciated in extant theological studies of ethics and the market; the labor power being exchanged in contractual relations "is embodied in a human being" (Kaufman \& Hotchkiss, 1997). Other features include the long-term nature of employment relationships, the sheer variety of workers and jobs, and asymmetries in information and labor mobility. It is the embodied nature of labor power that uniquely structures labor market analysis.

Ironically, religious social teachings, particularly the RCST corpus, engage such fields in detail: from objective/subjective dimensions of the employee's productivity to the social ecology responsibilities of the direct and indirect employers. Industrial relations scholars study the web of rules governing employment relations (Dunlop, 1958; Dunlop, 1993; Kaufman, 2004); those interested in a theology of the workplace study how authenticity in employment can be enhanced (or restricted) by these same web of rules, or employment parameters, at various analytical levels, in light of religious social teaching.

\section{Method}

This paper combines theory development with data analysis. The first step is a thorough review of authenticity in Western culture, management, philosophy, and employment studies for

\footnotetext{
${ }^{2}$ I am grateful to a Department colleague for raising a question about the meaning and significance of "authenticity" for theology of the workplace analysis in an earlier paper on the subject, discussed at a November 2012 Department research cluster session.

${ }^{3}$ For management spirituality or heroic leadership, see by way of example, (Benefiel, 2013; Lowney, 2003).
} 
conceptual mapping. Second, we review QST and RCST data sources for correlations and further specifics about the criterion variable. Two Figures will present what is known prior to the QST/RCST data analysis and then what can be inferred for criterion variable content specifics from the two traditions that were explored.

Insofar as this analysis is theological, there is a normative component; we seek to operationalize workplace authenticity. Thus, we are specifying a criterion variable, not a dependent variable. Criterion variables are common in social science when threshold or expected performance is assessed, such as academic success in studies (Jagacinski \& Flach, 2003).

Theology of the workplace analysis differs in method from management spirituality studies. The latter seeks "a framework of organizational values evidenced in the culture that promotes employees' experience of transcendence through the work process, facilitating their sense of being connected to others in a way that provides feelings of completeness and joy" (Giacalone \& Jurkiewicz, 2003, p. 13). This conceptualization admits of normative, positive expectations. Yet, the two methods are distinct and complementary. Management spirituality studies prescind from official religious teaching or doctrine. ${ }^{4}$ In contrast, a theology of the workplace embraces social teaching doctrine as an historically important source, but sees it as one blade of analysis that also requires the data of history, nation, culture, which impact authenticity prospects for workplace relations (Lonergan, 1971).

And what of contemporary theological method itself? Theology "mediates between a cultural matrix and the significance and role of a religion in that matrix" (Lonergan, 1971, Kindle Location, KL: 146). Theological reflection occurs in the interface between ever-to-berenewed religious thought and evident, emergent, cultural patterns (Melchin, 1988). Culture is

${ }^{4}$ The Handbook of Workplace Spirituality and Organizational Practice has but six references to "theology" in 500 pages, only one of which occurs in the text, the rest are title citations (Giacalone \& Jurkiewicz, 2003). 
readily defined as "the set of meanings and values that informs a way of life" (Lonergan, Op. cit., KL 149). Lonergan wrote, "When culture is conceived empirically, theology is known to be an ongoing process, and then one writes on its method" (Lonergan, 1971, KL: 152). Doran noted that the question of the situation is a crucial source for theologizing. He wrote, "The situation which a theology addresses is as much a source of theology as are the data provided by Christian tradition" (Doran, 1990, p. 8)..$^{5}$

\section{Criterion Variable Data: Authenticity}

Authentic is the adjectival form of authenticity, a noun indicating that something is as claimed - an authentic signature - or genuine. Common definitions include conforming to reality, being real, and, in consequence, worthy of trust or belief. A routine etymological search indicates this English word is related to French (authentique), Latin (authenticus), and Ancient

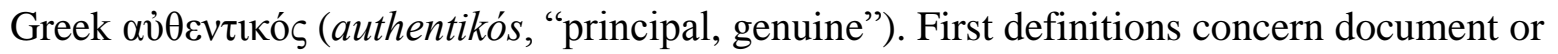
other item genuineness, which do imply human judgment. Authenticity, in reference to the quality of a life or society, or an inner sentiment, is more complex, albeit intuitively grasped at the level of common sense. It is a noun with the peculiar quality of inherently posing a question.

In 399 B.C.E., Socrates spoke of self-examination, as noted in the title, while facing a death sentence for corrupting the minds of youth and impiety. Socrates refused to "mind my own business" and took up "goodness and all the other subjects about which you hear me talking" (Hamilton \& Cairns, 1961). Socrates left no written record; the power of his words comes to us through his students, Plato and Xenophon, and his satiric treatment at the hands of playwright

\footnotetext{
${ }^{5}$ This research effort should also enhance recent steps towards a theology of social grace; "so the presence of grace can be acknowledged also at the levels of cultural and societal values with an impact on vital values" (Doran, 2011, p. 14). See also (Doran, 2010; Doran, 1990).
} 
Aristophanes. Pre-Socratic philosophers raised compelling questions, but the history of selfexamination for philosophy and citizenship can be directly traced to Socrates.

Augustine of Hippo brought a new dimension to the examined life in The Confessions (397-8 C.E). His examined life included conversion to Christianity (Augustine of Hippo, 1991). Through the Confessions, we witness an effort to reconcile Christian faith with the search for truth as known within a Neo-Platonian tradition (O'Connell, 1989). Augustine saw the institutional church as proxy, drawing two conclusions. First, the Christian church is superior to the state. Second, this church should infuse secular society with its better virtues.

Trilling explained in Sincerity and Authenticity that sincerity was the dominant concern of the reflective life over a 400 year span (Trilling, 1971). ${ }^{6}$ Sincerity entered the English language from Latin early in the sixteenth century. It is "the avoidance of being false to any man through being true to oneself," but this state "of personal existence is not to be attained without the most arduous effort" (Ibid., p.6). Authenticity, in contrast, suggests "a more strenuous moral experience than 'sincerity' does, a more exigent conception of the self and of what being true to it consists in, a wider reference to the universe and man's place in it, and a less acceptant and genial view of the social circumstances of life" (Ibid., p. 11).

Søren Kierkegaard’s writings marked a shift in concern from pietistic sincerity to authenticity. In an August 1, 1835 journal, he wrote of seeking "a truth which is truth for me, to find the idea for which I am willing to live and die" (Kierkegaard, 2007, p.19). In contrast to Augustine, Kierkegaard was driven to this in no small part by disillusionment with institutional Christianity itself. His writings serve "as a sort of temporary scaffolding to be abandoned once it has served its purpose, namely, to evoke and inspire readers to live authentic lives and to do so intensely 'without regrets' (Golomb, 1995, p. 36).

\footnotetext{
${ }^{6}$ He does not precisely specify this span.
} 
This authenticity involves "a kind of correlation between the 'what' of commitment and the 'how' of committing oneself' (Golomb, 1995, p. 62). As St. Amour wrote, "Kierkegaard realized that a culture enamoured by abstract and impersonal systems is liable to depreciate the task of striving to become a self” (St. Amour, 2002, p. 90). Furthermore, “...Kierkegaard hoped that individuals would humbly return to themselves and strive to appropriate authentic potentialities latent within the apparent poverty of the neglected subject”' (Ibid., p. 92). By the time of Nietzsche, Golomb reported various dimensions of congruence in reference to authenticity; "Authenticity denotes, among other things, a state of integrity between the innermost self and its external manifestations, whatever their form and content" (Golomb, 1995, p. 79).

In the first half of the $20^{\text {th }}$ Century, authenticity was taken up by Buber and Heidegger. Buber wrote, "Man can do justice to the relation with God in which he has come to share only if he realizes God anew in the world according to his strength and to the measure of each day. In this lies the only authentic assurance of continuity" (Buber, 2000). Buber extended his intersubjective analysis to community, constituted by a circle formed of "men's relations with their true Thou, the radial lines that proceed from all the points of the I to the Centre" (Ibid., p. 108). However, "It is not the periphery, the community, that comes first, but the radii, the common quality of relation with the Centre. This alone guarantees the authentic existence of the community" (Ibid., pp. 109).

In Heidegger's 1927 publication of Being and Time, "the importance of authenticity (the conversio vitae) resides in the need to provide a foundation for fundamental ontology - the question of Being” (Braman, 2008, KL 180). Through Heidegger, 'Dasein,' which translates to “there-being," entered the English language. In this regard, Richardson wrote that Heidegger, 
never defines explicitly what he means by "authenticity," but he offers the following ingredients for a definition: There-being is its own potentiality; as its own potentiality, it can "choose" itself in its own Being, i.e., "assume" itself; it can also "lose" itself, or rest in only an apparent assumption of itself. It There being achieves itself, it is authentic (eigentlich); if it fails to achieve itself, it is inauthentic (uneigentlich). Hence, both authenticity and inauthenticity are fundamental modes of Being (Seinsmodi) and have their basis in the fact that There-being, as existential, is a to-be-achieved-There (Richardson, 2003, p. 50).

Tracing developments in $20^{\text {th }}$ century existential authors, such as Camus and Sartre, Golomb wrote, "Authenticity, we saw, is best forged and revealed in 'boundary' or extreme existential situations. Yet such circumstances presuppose a social context” (Golomb, 1995, p. 201).

Adorno, in The Jargon of Authenticity, took on Buber's I-thou relation no less than Heidegger's Dasein and more, all for a critical perspective concerning what such scholarship appeared to accomplish. Of Buber, Adorno wrote, "nothing natural has gone through death without metamorphosis. Buber errs because his approach over elevates the dynamism of mortality into the sphere of immortality" (Adorno, 1973, p. 17). Heidegger, in turn, "instituted authenticity against the they and against small talk....But he did not foresee that what he named authentic, once become word, would grow toward the same exchange-society anonymity against which Sein und Zeit rebelled” (Ibid., pp. 17 - 18).

Adorno used Walter Benjamin's notion of "aura” to explain the jargon of authenticity. He wrote, "As words that are sacred without sacred content, as frozen emanations, the terms of the jargon of authenticity are products of the disintegration of the aura" (Ibid., p. 10). The Adorno critique of jargon was not limited to philosophers; "Innumerable real-life people speak it, from the student who in his exam lets himself go on about authentic encounter, to the bishop's press secretary..." (Ibid., p. 19). Adorno summarized his position as follows; "Philosophical banality 
is generated when that magical participation in the absolute is ascribed to the general concept $-\mathrm{a}$ participation which gives the lie to that concept's conceivability" (Ibid., p. 51). ${ }^{7}$

In 1968, Amitai Etzioni published The Active Society (Etzioni, 1968). He claimed that a radical transformation of technologies associated with communications, knowledge, and energy began after World War II. We see "continued increase in the efficacy of the technology of production which poses a growing challenge to the primacy of the values these means are supposed to serve" (Ibid., p. vii). How would society retain mastery over these technologies? Central to this goal is an active orientation to society by individuals, which has three components: the self-conscious actor, one or more goals to which the actor is committed, and "access to the levers (or power) that allow resetting of the social code" (Ibid., p. 4). Etzioni focused on employment issues, for which, "authenticity exists where responsivesness exists and is experienced as such" (Ibid., p. 620). Inauthenticity then becomes a subset of alienation. It is specified as a relation, institution, or society giving "the appearance of responsiveness while the underlying condition is alienating" (Ibid., p. 619). Not limited to business, inauthenticity may also become prevalent in labor unions, when these cease to authentically respond.

Rounding out the past century on this subject, Charles Taylor published The Ethics of Authenticity in 1992 (Braman, 2008; Taylor, 1992). He identified three issues of 'malaise' in modern society: individualism, the primacy of instrumental reason, and a political concern about the consequences of the first two. He proposed authenticity as a moral remedy to the lack of a deeper discourse in society, this due to a disingenuous liberal relativism in culture regarding the notion of what genuinely constitutes "a good life". Recalling the elusiveness of Dasein, Taylor wrote, "The result is an extraordinary inarticulacy about one of the constitutive ideals of modern

\footnotetext{
${ }^{7}$ We will see this ironic quality of authenticity jargon echo later in the "authenticity paradox" of CEO leadership portrayals (Guthey \& Jackson, 2005)
} 
culture..." (Ibid., p. 18). Taylor's agenda requires three assents. First, that authenticity is a valid ideal. Second, that ideals and practical conformity can be reasonably argued. Third, that argumentation can make a difference.

Comparative employment doctrine, authentic leadership and employment relations

\section{studies}

We can address the last theme first, for two reasons. First, employment relations are at the heart of this research agenda. Second, there does not seem to be any prior research that directly takes up the term authenticity in respect to employment relations or employment contract law, at least not in respect to authenticity as a criterion variable.

However, as we are exploring employment relations and their national parameters, we should consider the U.S. employment contract and "American exceptionalism." This is because the management literature, which takes up authenticity - particularly in respect to leadership studies - is often focused upon and derives from the U.S. employment context.

According to the National Conference of State Legislators, America "is but one of a handful of countries where employment is predominantly at-will. Most countries throughout the world allow employers to dismiss employees only for just cause" (National Conference of State Legislators, 2013). The U.S. is, in fact, the "world's only major employment-at-will jurisdiction," with certain federal statutory restrictions against discrimination and one particular state's rather remarkable legislative exception (Pitchford, 2005; White \& Case Law Firm, September 2011). While employment at will is treated as a rule or doctrine, it functionally reflects a sheer absence of policy. Thus, only Montana has opted to fill this absence, having established just cause dismissal protections in 1987 state legislation (National Conference of State Legislators, op. cit). 
The legal ground of U.S. employment at-will is the 1877 text by Horace Gray Wood, written in respect to servant claims regarding length of employment (Wood, 1877). The decisive passage is this;

With us the rule is inflexible, that a general or indefinite hiring is prima facie a hiring at will, and if the servant seeks to make it out a yearly hiring, the burden is upon him to establish it by proof...It is an indefinite hiring and is determinable at the will of either party, and in this respect there is no distinction between domestic and other servants (Ibid., p. 272).

Feinman cited an 1870 text by James Schouler, Domestic Relations, in which master servant law as it was developing in the U.S. at that time was extended to corporate employees “as servant by analogy” (Feinman, 1976, p. 123). Despite a serious of citation errors in Woods' text that were necessary supports for his conclusion, all of which are famously known to be wrong today, this judicial principle - this "absence" - diffused throughout legal precedent in the United States and remains institutionalized legal practice. Except, that is, for Montana.

Yet, in consequence, the American employment relation persists in modeling a masterservant analogy in which the employer purchases the total product of the worker, who has no residual or more intrinsic right to the product of her/his labor power. Feinman wrote, "Employment at will is the ultimate guarantor of the capitalist's authority over the worker." He continued, "If employees could be dismissed on a moment's notice, obviously they could not claim a voice in the determination of the conditions of work or the use of the product of their labor" (Ibid., p. 132-3). ${ }^{8}$

In what other ways does American exceptionalism change employment relations? The 'at-will' employment premise effectively eliminates legal grounds for participatory voice in managerial prerogative: a second-dimension consequence. Through different ways and means, employees in other nations frequently have formal voice in managerial prerogative (Rogers \&

\footnotetext{
${ }^{8}$ We will later see this is completely at odds with both QST and RCST, particularly the latter.
} 
Streeck, 1995). In the E.U, works councils exist beside labor unions, mandated by legislation (Blanpain, 1998; Union, 1994). In Japan, "management councils" co-exist with labor unions, with council role and function determined by collective bargaining agreements (Tackney \& Sato, 2012; Tackney, 2001). The historical development of these institutions was noted by Streeck in 1995;

Today the remarkable fact of the almost universal establishment of works councils after 1945 in otherwise very different national contexts, as an integral part of a worldwide recasting of the political economy of capitalism after the economic and political catastrophes of the interwar period, is largely forgotten" (Streeck, 1995, p. 313).

A review of authenticity in management studies, particularly given the ironic feature of American exceptionalism, can usefully begin in light of a philosophical thread linking authenticity to the aesthetic experience. Let us consider organizational emphasis on authenticity in executive portraits. It may be far afield from employment relations, but the research speaks to corporate perceptions of increased need for "presence, visibility and authenticity" (Guthey \& Jackson, 2005, p. 1058). Guthey and Jackson wrote, "visual presence has functioned as a traditionally accepted prerequisite for authenticity" (Ibid.). The authors explored the particular and peculiar challenge of such portraiture. There is the legal person of the disembodied corporation; there is the human CEO. Photographic efforts to reconcile these facts become ever more expensive, and authenticity more elusive. The authors capture the countervailing tensions in what they characterize as the "authenticity paradox" of portrait effort and actualization.

A similar paradox of authenticity may be at work in leadership studies: the more authenticity in leadership is asserted in the American context, given the master-servant analogous contract law grounding, the more elusive it may become. Freeman and Auster refer to the "Problem of Authenticity" (Freeman \& Auster, 2011); "how we know our values or whether our values are realizable through action" (p. 7). The authors characterize being authentic as "an 
ongoing process of conversation that starts with perceived values, but also involves one's history, relationship with others, and aspiration" (p. 2). ${ }^{9}$ While calling for sensitivity to the poetic self, there is no prescription for employment contract authenticity. The Freeman and Auster text calls attention to definitional weaknesses in management studies of authenticity, but also manifests a few of their own. Values, for example, seem ill defined as "preferences".

Authentic leadership is a recent development (Northouse, 2013). It is less formally or less well-defined than other leadership approaches (trait, skills, style, situational, psychodynamic), leadership theories (contingency, path-goal, leader-member exchange) or leadership types (transformational, servant, team). Upheavals in "society" are cited to explain the increased interest (Gardner, Cogliser, Davis, \& Dickens, 2011; Northouse, 2013). ${ }^{10}$ Scholars appear motivated to find the 'root' of positive forms of leadership - and believe authenticity is a defining quality (Avolio \& Gardner, 2005). Northouse reports authentic leadership definitions reflect intrapersonal, interpersonal, or developmental perspectives. Precursors can be found in transformational leadership research (Bass, 1985; Burns, 1978; Northouse, 2013). Psychology, particularly humanistic psychology, is a remote inspiration (Erikson, 1950; Maslow, 1968).

Intrapersonal definitions of authentic leadership look to characteristics of the individual for qualities that evidence authenticity: self-knowledge, genuineness, and a sense of conviction. Life course and meaning may contribute. The interpersonal approach examines relational interactions between leader and followers (Eagly, 2005). The developmental path sees

\footnotetext{
${ }^{9}$ The authors do not specify with whom this 'conversation' occurs: an internal dialogue like Kierkegaard, or a more complex discourse between public, private self and one's working colleagues and environment? ${ }^{10}$ Here, both cited texts referenced exclusively U.S. events: Enron and WorldCom corporate scandals, 2009 global banking crisis (largely, if not entirely, U.S. in origin due to Federal Reserve policy changes under Alan Greenspan), and the 9/11 terrorist attacks. This is not to challenge the merit of their claims, only to observe their context as emergent patterns in culture.
} 
authenticity as a refinable quality, including self-awareness, one's moral perspective, balanced processing, and relational transparency (Avolio \& Gardner, 2005).

Northouse distinguished practical and theoretical literature on authentic leadership. Terry offers an Authentic Action wheel with fulfillment at the center, surrounded by segmented inner and outer circles where the inner circle item points to the next outer circle item in a practical graphic: mission $>$ meaning $>$ existence $>$ resources $>$ structure $>$ power $($ Terry, 1993). George attempts to fill out the presumptive elements of apprehending the "good" in Terry's actionoriented approach. In 2007 , he defined $21^{\text {st }}$ century authentic leaders as those "who bring people together around a shared mission and values and empower them to lead, in order to serve their customers while creating value for all their stakeholders" (George, 2013, p. 12). Five key factors are linked to developmental qualities: purpose / passion, values / behavior, relationships / connectedness, self-discipline /consistency, and heart / compassion (George, 2004).

To summarize current theoretical components of authentic leadership, four key items are empirically important: self-awareness, an internalized moral perspective, balanced processing, and relational transparency (Walumbwa, Avolio, Gardner, Wernsing, \& Peterson, 2008). The Walumbwa et al. study is notable for its multinational data sources: China, Kenya, and the United States. These authors defined authentic leadership as

a pattern of leader behavior that draws upon and promotes both positive psychological capacities and a positive ethical climate, to foster greater self/awareness, an internalized moral perspective, balanced processing of information, and relational transparency on the part of the leaders working with followers, fostering positive self/development (Ibid., p. 94).

Authentic leader research prompted authentic follower studies. A 2010 paper reported a "positive link between authentic leadership and follower work engagement as well as follower OCB (organizational citizenship behavior) (Walumbwa, Wang, Wanh, Schaubroeck, \& Avolio, 
2010, p. 910). Leroy, Anseel, Gardner, and Sels studied follower authenticity in Belgium (Leroy, Anseel, Gardner, \& Sels, 2012). One aspect of the Leroy et al. research is their effort to assess both individual and group dynamisms. They discovered, "authentic leadership...makes it more likely that followers come to feel that they are the author of their work-related behavior through the satisfaction of their basic needs" (Leroy et al., 2012, p. 15).

There are other leadership approaches. None take up authenticity to the degree of authentic leadership / followership studies with one exception: the servant-leader genre identifies authenticity as an essential component. Servant-leadership was developed by Robert Greenleaf (Greenleaf, 2003; Greenleaf, 2002). Yet, as closely attuned to notions of authenticity as servant leadership may be, it is less a goal than a given quality for servant-leadership ends. Secular by design, infused with Judeo-Christian references and inspirational support, servant-leadership presumes the underlying employment parameters of its national origins.

<Figure 1 about here.>

An initial assessment of authenticity in our literature review in general reference to employment relations can be summarized in Figure 1. What has been established is in black ink. Indeterminate norms and conditions are green. What are the enabling conditions for authenticity on the part of employer and employee in respect to authentic behaviors? In terms of authenticity, the normative status of the employment contract itself is indeterminate. U.S. "at will" employment suggests equality, but is historically grounded in a master-servant employment analogy. Is it a contract between "at will" equals? Or, should just cause protection redress a fundamental inequality in employment contract law? Aside from Etzioni, the literature on authenticity scarcely takes up contract, labor unions, or managerial prerogative. What is the 
status of labor unions from a theology of the workplace analysis? And what of employee participation in managerial prerogative?

With these questions in mind we now turn to the work of Bernard J.F. Lonergan (Lonergan, 1971; Lonergan, 1992). His approach is last because it is the most comprehensive for the analysis being developed. ${ }^{11}$ He specifies conditions for authenticity in culture, accounts for sources of error at individual and higher levels, and acknowledges cultural decline - including the possibility of decline in religious authenticity, and offers steps for recovery.

\section{Authenticity in the epistemology and theological method of Bernard J.F. Lonergan}

Lonergan's first reference to authenticity in human living occurs in an introduction to the aesthetic pattern of experience in his epistemology text, Insight.

There exists in man an exuberance above and beyond the biological account books of purposeful pleasure and pain. Conscious living is itself a joy that reveals its spontaneous authenticity in the untiring play of children, in the strenuous games of youth, in the exhilaration of sunlit morning air, in the sweep of a broad prospective, in the swing of a melody (Lonergan, 1992, p. 207).

Here, Lonergan links two facets of authenticity. One is spontaneous; the other "broad perspective" comes from prior learning, reflection, and steady effort. The other reference to authenticity of interest in his text occurs in the thick of distinguishing an analysis of cognitional operations and cognitional structure from Kantian transcendental deduction. This statement speaks to the second authenticity, one that is, "self-authenticating and decisive." The text also provides our first process account of Lonergan's insight-based critical realism;

Inquiry is about the data of sense of or consciousness. Insight is into the data of inquiry. Concepts and theories are the products of insight and have to be checked against the data. Moreover...the process of checking reveals in human knowledge, beyond experience and understanding, a third, distinct, constitutive level that is both self-authenticating and

\footnotetext{
${ }^{11}$ Lonergan's contributions to macro-economic theory are beyond the scope of this study, but should be noted (Lonergan, 1998; Lonergan, 1999).
} 
decisive. ...Again, the third level alone is decisive: until I judge, I am merely thinking; once I judge, I know; as insight draws the definite object of thought from the hazy object of experience, so judgment selects the objects of thought that are objects of knowledge. Finally, ...to know means to know being, and to know being includes knowing objects and subjects (Lonergan, 1992, p. 364).

Lonergan invites personal reflection on one's consciousness, because this can lead to self-appropriation: a personal grasp of the steps from initial experience to insight. Selfappropriation can indicate a cognitional structure underlying all human endeavors.Insight is that moment of 'seeing into' connections between notions, "getting the point." Reflection on the features of such moments reveals that insight: comes about as release from inquiry, may be sudden and unexpected, is a function inner conditions, pivots between the concrete instance and the abstract, and becomes part of "the habitual texture of one's mind" (Lonergan, 1992, pp. 3-4). As Vertin explained, “It's really that sensation (or, more broadly, experience) plus inquiry lead $\underline{\text { to }}$ direct insight and formulation (on level 2); those plus reflection lead to reflective insight and judgment (on level 3); and those plus deliberation lead to deliberative insight, evaluation, and choice (on level 4)". ${ }^{12}$ In Chapter 10 of Insight, Lonergan schematically presented "three levels of cognitional process." The third level was nuanced into four aspects of cognitional operations in Method in Theology (Lonergan 1999, Vertin, 1995):

1. Immediate experience: data, perceptual images, feelings, free images, utterances: - The giveness of being and the unrestricted desire to know.

2. Questions for intelligence: insight and formulation:

- Inquiry as mode of questioning: what, why, when, and how often?

- The basic operational dynamism: the transcendental notion of intelligibility.

3. Reflective insight: questions for reflection, leading to judgment:

- Reflection as questioning mode: Is it? Is this real? Is that really so?

- The basic operational dynamism: the transcendental notion of reality.

4. Deliberative insight: questions concerning value-related deliberation:

- Deliberation as the questioning mode: Is it good? Ought that be so?

\footnotetext{
${ }^{12}$ In email correspondence to author on 5 February 2011.
} 
- The basic operational dynamism: the transcendental notion of valuability.

In level three, the prospective judgment concerns insight of fact. At the next level, judgment concerns value. For management and organization studies, this would be the level of assessment involving the quality of insight and deliberation that yields judgments in respect to, for example, the merits of specific policy proposals. In this, Lonergan noted, "our realism, while not intuitive, will be immediate; cognitional analysis is needed not to know being but to know knowledge" (Lonergan, 1992, p. 365).

Consistent authenticity obliges a steadfast orientation to the key precepts: be attentive, intelligent, reasonable, and responsible. This insight-based critical realism offers a basis for cross-cultural reflection, analysis, and application. Doran observed,

The common ground on which people can meet in our time is twofold. There is a common structure of consciousness shared across cultures, a structure of operations through which we come to know and through which we proceed from knowledge to action. That common structure Lonergan expresses in a shorthand vocabulary as consisting of the four levels of experience, understanding, judgment, and decision (Doran, 2011).

To some degree, these different levels of cognitional operation proceed regardless of reflection. The process can be practically instantaneous. Consider the driver approaching a busy corner at a yellow light, who faces the decision: hit the brakes or speed through. She operates at nominal attentiveness, notes the changing external stimuli of green light gone yellow. A judgment is rapidly reached about what to do. Reasonableness issues might include the presence or absence of children in the car, weather conditions, or prior convictions for traffic violations. The decision to brake is specific. Authenticity in such decision-making is evidenced by our care and reasonableness throughout the process. ${ }^{13}$

\footnotetext{
${ }^{13}$ For a useful pedagogical text on this subject, see (King, 2011)
} 
There are two important aspects to the traffic light example. First, there is the obvious individual drama. The second aspect consideres this drama as it unfolds within a complex social fabric frequently presumed, indirect, yet very real. On a daily basis we make countless individual decisions within this social commonweal. The individual accommodation to societal norms takes time; social norms also change. ${ }^{14}$ Not everyone passes their first driver's test. With a sick child in the car, traffic lights may be justifiably ignored to get to the hospital.

Doran wrote, "Authenticity is achieved in self-transcendence, and consistent selftranscendence is reached only by conversion" (Doran, 2011, p. 2). Doran points to human development issues here; one must change by growing up, and becoming one's true self involves recognizing that which is beyond the self. Conversion in Lonergan's use does not mean conversion only in the religious sense. Instead, it refers to fundamental changes that accompany human development. Conversion may be intellectual, moral, religious, or psychic. Moral conversion "may approach consistent moral integrity; but on the other hand it may be a continual matter of picking oneself up and starting over" (Doran, 2011).

Underlying and informing this analysis, we have Lonergan's epistemological theorem; "knowledge in the proper sense is knowledge of reality or, more fully, that knowledge is intrinsically objective, that objectivity is the intrinsic relation of knowing to being, and that being and reality are identical" (Lonergan, 1988, p. 211). In Method in Theology, Lonergan builds upon this theorem by linking authenticity to developments in society and culture. He wrote, “Authenticity can be shown to generate progress, unauthenticity to bring about decline, while the problem of overcoming decline provides an introduction to religion” (Lonergan, 1971, KL 4494). Minor issues of authenticity concern relational decisions of individual to institutions; major issues of authenticity concern the fabric of the institutions themselves. As Lonergan wrote,

\footnotetext{
${ }^{14}$ For a text on public policy and its 'invisible' role in employment, see (Befort \& Budd, 2009).
} 
"In the first case there is passed a human judgment on subjects. In the second case history and, ultimately, divine providence pass judgment on traditions" (Ibid., KL 1335).

Authenticity is a quality of being human to be sought, nurtured, and sustained through attentiveness, intelligence, reasonableness, and responsibility in decision-making. This may be empirically assessed at individual and societal levels. When cultural patterns of authenticity obtain, these manifest a good of order in society; "in the world mediated by meaning and motivated by value, objectivity is simply the consequence of authentic subjectivity, of genuine attention, genuine intelligence, genuine reasonableness, genuine responsibility” (Ibid., KL 4134).

To summarize, authenticity has a special role to play in assessments of human endeavor. It is sincerity, but with a certain street-wise, critical sensibility. From the time of Socrates, human beings have sought to live an examined life, even and especially when at variance with a societal status quo. In Christian history, the notion of individual responsiveness to a personal God brought about a historical role for religion and church, only to be itself called into question by the time of Kierkegaard. Heidegger's effort to found ontology without God was seen to engender a new genre of jargon posing as authenticity. Eztione and Taylor offer diagnosis and prescription, yet, we will see, do not provide adequate specificity for thought or specific actions.

\section{Authenticity in Employment Relations: The Religious Society of Friends Social}

\section{$\underline{\text { Teaching }}$}

The Religious Society of Friends (Quakers) ${ }^{15}$ held their first recorded Yearly Meeting in the English county of Bedford in spring of 1658, at the house of John Crook, who was a local justice. Quaker Social Teaching (QST) has been grounded in individual leading and shared reflection from Meeting experience since their founding. There is no single voice, no hierarchical

\footnotetext{
${ }^{15}$ Members of the Religious Society of Friends are called / refer to themselves as "Friends" or "Quakers."
} 
teaching authority. The Friends are worthy of study due to their remarkable business success. Unlike some Protestant denominations, "the Quakers went out into the world rather than withdrawing from it" (Windsor, 1980, p. 170). For Friends, individual liberty of conscience was and remains a key ethic due to belief in the presence of an inner light within each individual. By attention to this inner light, each person may directly perceive the presence of God. Individual guiding by this inner light led Friends variously in England, later the American colonies, and eventually throughout the world in comparatively small, if very committed numbers. ${ }^{16}$ In turn, individual leading by this inner light was tested in larger Friends Meetings from the founding days, hence the importance of Meeting and query. Cooper wrote, "Although their involvement in either politics or business has never been officially under the care of the Meeting, Friends have exercised testimonies that have attempted to admonish and sometimes restrain their members in carrying out such endeavors" (Cooper, 1990, p. 166)

The early Friends in England were not allowed professional positions, which opened their way to commerce (Windsor, 1980). While never exceeding one percent of the U.K. population, their commercial interests included raw materials, manufacturing, communications, canals, railways, and banking. Friends earned respect for social welfare: penal reform, hospitals, education, housing, and opposition to slavery. They "flowered within two or three generations to become dominant influences in towns and cities across the country" (Windsor, op. cit., p. 1).

In business practices, Quakers stood by a single price system, prompt payment of debts, and transparency in all dealings. Friends social testimony included refusals to take oaths, use titles of honor, tithe, opposition to war or fighting. Instead, they embraced simplicity, honesty, and plain manner in speech, dress, and lifestyle (Cooper, 1990). Windsor, in his study of $18^{\text {th }}$ and

${ }^{16}$ There are about 359,000 Friends in the world at present (Quaker Information Center). This section relies mostly on U.K. Quaker texts. 
$19^{\text {th }}$ century Quaker enterprises in Britain, reported no 'magic 'ingredient' to explain their unique success of the Friends in business" (Windsor, 1980, p. 166). There was no cause in group origins or precursor ethic, region, culture or common social status. They had a Protestant work ethic; work was its own end, something to be admired, and it helped in the cultivation of character and soul. Instead, Windsor attributed Quaker success to the "particular combination of these elements" (Ibid., p. 167). ${ }^{17}$ In colonial America, the early impact of Friends migration was profound, the long-term effect enduring (Jones, 1911).

In 1916, Friends Yearly Meeting in the United Kingdom held a conference to address issues of war and social order. The Conference settled on "The Seven Points of the Message to all Friends" (Devonshire House Conference). Their fourth point took up industrial society.

Our belief in the futility of the methods of outward domination, and of the appeal to force, applies not only to international affairs, but to the whole problem of industrial control and to the resort to industrial strife. Not through antagonism, but through cooperation in its widest sense, will the best be achieved for each and all (Ibid.).

More recently, social testimony of Friends continues to center on qualities of integrity, simplicity, peace, and equality (Cooper, 1990; The Quakers and Business Group, 2000). Integrity "is a testimony rooted in the Quaker respect for truthfulness" (Cooper, 1990, p. 132). Still, Cooper noted, "The extent to which Quaker testimonies have affected Friends in the workplace and in public service is difficult to assess" (Ibid., p. 167). Currently, the Quakers in Britain site features queries on employment (Quakers in Britain, 2013). While these tend toward compliance with U.K. labor laws, the "good employer" advice goes far beyond:

- Communicating regularly

- Helping employees to achieve - dealing with any blocks to them achieving

- Demonstrating trust

- Genuine listening and considering the employee's views

- Providing support at times of difficulty

- Treating employees fairly and valuing them for their differences

${ }^{17}$ For a list of Quaker contributions to industrial capitalism, see (Davison, 2011). 
- Organising work so that it promotes initiative

- Valuing people - recognising good performance and work

- Being honest and open about underperformance, with an aim to assist improvement

- Encouraging employees to learn new skills relevant to the job

- Providing a safe and healthy workplace (Quakers in Britain, 2013).

"The Quakers and Business Group" has a text, Good Business Ethics at Work (The Quakers and Business Group, 2000). Taking the traditional form of advice and queries, the text queries about profit. Is it excessive profit? Is there a temptation to increase profits simply because the market can bear this move? Remuneration levels are queried: the range of compensation between most and least. A query is posed regarding remumeration: "Is your remuneration linked to profitability, even when this has been achieved by making others redundant?” (Ibid., p. 22). The text encourages the creation of opportunity for employees. The employer is advised about relations with trade unions, encouraged to nurture trust, and urged to seek outcomes offering a "win-win outcome for both parties" (Ibid., p. 32). There is this query: "Do you consider employer and trade unions as colleagues, each of whom has a worthwhile contribution to make to the business?" (Ibid., p. 33).

Friends approach to employment relations tends to be practical, giving advice and posing queries to clarify thought with a view to consensual participation in all affairs. Business leader roles are recognized and various stakeholder input valued, even consensually so; "From time to time we all called upon to lead...Planning to realize a vision is not sufficient - it is necessary both to make a decision and act" (Ibid., p. 37). Authenticity in employment relation is, therefore, actualized by Friends practice of their favored qualities: integrity, simplicity, peace, and equality. Absent any formal teaching authority by deliberate intent, Friends seek to manifest the peaceable kingdom today, as they live. Cooper wrote, "The crux of the problem for Friends is that they seldom make any distinction between a personal ethic and a social ethic" (Cooper, 1990, p. 80). 


\section{Authenticity in Employment Relations: Roman Catholic Social Teaching}

In contrast to the deliberately diffuse QST, RCST can be traced through a series of Papal encyclicals and allied documents from Pope Leo XII in 1891, Rerum Novarum (Leo XIII, 1891), ${ }^{18}$ to the recent Exhortation of Pope Francis, Evangelii Gaudium (Francis, 2013). As a first effort at theorizing on authenticity, only the major RCST documents will be studied. ${ }^{19}$

We can begin with the recent Exhortation, by assessing the discourse taken on authenticity. Three text uses warrant review. The first concerns authenticity of gifts (charisms) given by the Holy Spirit for the evangelizing Church. Here, Francis notes a sign of authenticity, “its ecclesial character, its ability to be integrated harmoniously into the life of God's holy and faithful people for the good of all" (P. 130). ${ }^{20}$ The second concerns personalization of the Gospel. Quoting Paul VI's Apostolic Exhortation, Evangeli Nuntiandi, Francis notes that people today "thirst for authenticity" (P. 150). He lists what will not satisfy this thirst: an economy of exclusion, the new idolatry of money, a financial system which rules rather than serves, and an inequality which spawns violence (P. 53-75). Conditions for authenticity in employment are stated in respect to the social inclusion of the poor. This means, "above all, employment, for it is through free, creative, participatory and mutually supportive labour that human beings express and enhance the dignity of their lives" (P. 192). A "just wage" is expected. Francis later writes about employment;

We can no longer trust in the unseen forces and the invisible hand of the market. Growth in justice requires more than economic growth, while presupposing such growth: it requires decisions, programmes, mechanisms and processes specifically geared to a better distribution of income, the creation of sources of employment and an integral promotion of the poor which goes beyond a simple welfare mentality (P. 204).

\footnotetext{
${ }^{18}$ RCST encyclicals are given in traditional Latin. English translations are given in References.

${ }^{19}$ Subsidiarity - keeping decisions to a local level - is an RCST and institutional principal. Much more is available at national conference, religious order (women and men), and even diocesan levels.

${ }^{20}$ For RCST documents, the citation refers to paragraph number $(\mathrm{P})$, not page number.
} 
RCST sources are entirely consistent with this Exhortation, as we will now see. Several essential conditions to an authentic employment relationship can be unequivocally inferred from the legacy of documents. The free association of employees in labor unions for the sake of collective representation is a recurring, constant theme, without exception. Modernization and developments since the industrial revolution have not changed RCST on this subject. A continuing employment relation, requiring just cause for termination, also recurs. Equally so, RCST persistently recognizes the right of property and ownership, albeit with obligations to the commonweal. Finally, the right to a living, not subsistent, wage for the worker, including support for her or his family, has steadily been asserted in Church teaching. ${ }^{21}$

As potential criterion variable, authenticity or 'authentic' actually occurs in later RCST. First multiple appearances of the word were in the 1965 Gaudium et Spes. A global "authentic economic order" requires an end "to profiteering, to national ambitions, to the appetite for political supremacy, to militaristic calculations, and to machinations for the sake of spreading and imposing ideologies” (Paul VI, 1965, P. 85).). In John Paul II's 1981 Laborem Exercens, the Church's task is to "call attention to the dignity and rights of those who work, to condemn situations in which that dignity and those rights are violated, and to help to guide the abovementioned changes so as to ensure authentic progress by man and society" (John Paul II, 1981, P. 1). In this text, attention centers on human work as "the key, probably the essential key, to the whole social question" (Ibid., P. 3, italics by John Paul II). A threat to the right order of values concerning the subjective dimension of work develops from its treatment as merchandise.

One theme clearly developed over the decades concerns the recognition that workers possess an inherent right to participate in the disposition of the product of their labor power -

${ }^{21}$ The points in this section recur persistently in each of the six encyclicals on the social question from Leo XIII to Benedict XVI (Benedict XVI, 2009; John Paul II, 1981; John XXIII, 1961; Leo XIII, 1891; Paul VI, 1965; Pius XI, 1931). 
even a preeminent right. RCST has consistently advocated moderation of managerial prerogative through formal or informal employee participation: the sharing of ownership, inclusive of risk (John XXIII, 1961; Paul VI, 1965; Pius XI, 1931).

With John Paul II's 1981 encyclical, RCST completely recast nominal presumptions

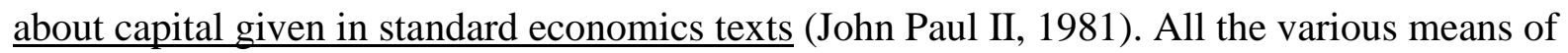
capital accumulation - from the gathering of natural resources to their most sophisticated manufactured refinement - "are the result of the historical heritage of human labor" (John Paul II, 1981, P. 12). John Paul II wrote, “Thus, the principle of the priority of labour over capital is a postulate of the order of social morality" (John Paul II, 1981, P. 15). There are implications:

A labour system can be right, in the sense of being in conformity with the very essence of the issue, and in the sense of being intrinsically true and also morally legitimate, if in its very basis it overcomes the opposition between labour and capital through an effort at being shaped in accordance with the principle put forward above: the principle of the substantial and real priority of labour, of the subjectivity of human labour and its effective participation in the whole production process, independently of the nature of the services provided by the worker (John Paul II, 1981, P. 13).

This position is explained and requires a complete quote;

All that we can say of everything in the production process which constitutes a whole collection of "things," the instruments, the capital, is that it conditions man's work; we cannot assert that it constitutes as it were an impersonal "subject" putting man and man's work into a position of dependence. This consistent image, in which the principle of the primacy of person over things is strictly preserved, was broken up in human thought, sometimes after a long period of incubation in practical living (Ibid., P. 13).

A criterion for authenticity in employment is later offered. John Paul II wrote,

it must be emphasized, in general terms, that the person who works desires not only due remuneration for his work; he also wishes that, within the production process, provision be made for him to be able to know that in his work, even on something that is owned in common, he is working "for himself" (Ibid., P. 15).

Economic systems premised on profit maximization will not succeed;

it is respect for the objective rights of the worker-every kind of worker: manual or intellectual, industrial or agricultural, etc.- that must constitute the adequate and 
fundamental criterion for shaping the whole economy, both on the level of the individual society and State and within the whole of the world economic policy and of the systems of international relationships that derive from it (Ibid., P. 18).

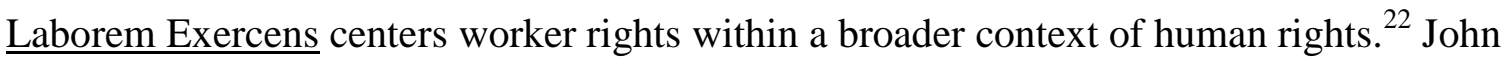
Paul II saw this as part of the Church's "particular duty to form a spirituality of work" (P. 24). Calling for an ethically correct labor policy to lead to an authentic human and social ecology of work, the encyclical distinguishes direct and indirect employer effects to assess just employment circumstances (P. 38). Direct employers contract an individual for employment. The indirect employer includes "many different factors, other than the direct employer, that exercise a determining influence on the shaping both of the work contract and, consequently, of just or unjust relationships in the field of human labour" (John Paul II, 1981, P. 16, Italics added). The indirect employer is, first of all, the state, which "must conduct a just labour policy" (Ibid., P. 17). But indirect employer influences include links between nations on trade issues, for example, when these impact employment relationships. Processes of internationalization and mutual dependence for economic ends may be aids or obstacles to just employment circumstances. As the gap between developed and disadvantaged societies increases, direct employers may find in this opportunistic advantage for greater profit to reduce wages and/or working conditions below "the objective requirements of the workers" (Ibid., P. 17).

Benedict XVI, in turn, called for a "Profoundly new way of understanding the business enterprise" (Benedict XVI, 2009, P. 40). This would come about when business managers assume responsibility for all "other stakeholders who contribute to the life of the business: the

\footnotetext{
${ }^{22}$ John Paul II noted that this link has been clearly made since at least John XXIII's Pacem it Terris; "As a further consequence of man's nature, he has the right to the private ownership of property, including that of productive goods" (John XXIII, 1963, P. 20). On the issue of appropriate compensation, John XXIII wrote, "The amount a worker receives must be sufficient, in proportion to available funds, to allow him and his family a standard of living consistent with human dignity" (John XXIII, 1963, P. 20). Here, John XXIII cited a Pius XII broadcast message, Pentecost, June 1, 1941, AAS 33 (1941) 201 (See footnote 17 in Pacem in Terris).
} 
workers, the clients, the supplier of various elements of production, the community of reference" (Ibid., P. 40). And, returning to the recent Exhortation, we find Pope Francis reminding the reader that his is not a social document; "for reflection on those different themes we have a most suitable tool in the Compendium of the Social Doctrine of the Church, whose use and study I heartily recommend" (Francis, 2013, P. 184).

The Compendium reaffirms what we know, writing, with emphasis, "It is essential that within a business the legitimate pursuit of profit should be in harmony with the irrenounceable protection of the dignity of the people who work at different levels in the same company" (Pontifical Council for Justice and Peace, 2005, P. 340). The document links markets and their analysis in a broader, reciprocally conditioning, moral and social ecology under the priority of labor. Authenticity in employment relations is expected to enhance business performance;

A business enterprise must be a community of solidarity, that is not closed within its own company interests. It must move in the direction of a "social ecology" of work and contribute to the common good also by protecting the natural environment" (Pontifical Council for Justice and Peace, 2005, P. 340).

Here, authenticity is the stated criterion; "From the standpoint of definitive goods, the lay faithful are able to engage in earthly activity according to the criteria of authenticity" (Ibid., P. 544). The criteria derive from Christian spirituality, which "precludes both an intimist spiritualism and a social activism, expressing itself instead in a life-giving synthesis that bestows unity, meaning and hope on an existence that for so many different reasons is contradictory and fragmented" (Ibid. 545). ${ }^{23}$ Employee participation is normative; "The relationship between labour and capital also finds expression when workers participate in ownership, management and profits. This is an all-too-often overlooked requirement and it should be given greater consideration" (Pontifical Council for Justice and Peace, 2005, P. 281. Italics in original text).

${ }^{23}$ The Compendium repeatedly refers to the 'laity' in this context, which is the population of Roman Catholics and people of good will who are not professed religious or diocesan clergy. 
The text recognizes emerging employment practices, but only to reinforce established RCST. Its authors wrote, "The new ways that work is organized, where knowledge is of greater account than the mere ownership of the means of production, concretely shows that work, because of its subjective character, entails the right to participate" (Ibid.). The Compendium situates the question of the worker within the commonweal;

The common good...involves all members of society, no one is exempt from cooperating, according to each one's possibilities, in attaining and developing it" // "Everyone also has the right to enjoy the conditions of social life that are brought about by the quest for the common good" (Ibid., P. 167). ${ }^{24}$

\section{Discussion}

We have examined the concept of authenticity and to assess its suitability as a criterion variable for theology of the workplace empirical analysis. This specification is given in Figure 2, which lists data specifics from QST and RCST in respect to authenticity conditions on both sides of the employment contract, affirmation of labor union, collective bargaining and participation rights, along with the direct / indirect employer features of RCST.

\section{< Figure 2 about here. >}

Figure 2 specifies the conditions for authenticity in employment relations. There are direct and indirect employer influences. Protection against at-will dismissal and structures for subjective worker participation in managerial prerogative are indicated. Categories of employer and employee work authenticity are distinguished by the precepts drawn from Lonergan's epistemology; these focus attention on concrete issues as these emerge in culture. QST principles of honesty, simplicity, peaceableness, and equality clarify and complement RCST conditions.

The RCST corpus is a well-organized social teaching literature. QST sources, in contrast, offer a complimentary, diffuse contribution to authenticity in employment relations. Both

\footnotetext{
24 "From each according to his ability, to each according to his needs!" (Marx, 1970, p. 5). We can only wonder if the Pontifical Council intended any such resonance to be perceived by potential readers.
} 
traditions offer regional and local social teachings. Nevertheless, the first step of functional criterion analysis across divergent Christian traditions is complete. Deriving comparative authenticity specifics from other traditions await: Buddhist, Hindu, Islam, and Judaic.

We can briefly return to the unionization effort at Duquesne University mentioned at the outset. An employment law analysis would be concerned with, perhaps satisfied by, the straightforward legal efficacy of an exemption claim. A theology of the workplace analysis finds the blatant disregard for union representation at a Roman Catholic university to be a major failure of institutional authenticity. It is, to recall Socrates efforts at living an examined life, sheer sophistry. Serious harm to employment authenticity aspirations occurs on at least two levels. First, Roman Catholics can only be dismayed by the undermining of trust in RCST displayed by this Catholic educational institution. Second, such acts of legal sophistry cause RCST harm at the indirect employer level: the school action suggests American Catholic institutions may operate with a preferential option for prevalent norms of American culture, against obvious, longstanding RCST, with its preferential option for labor and the worker.

Theology of the workplace analysis should help integrate religious social teaching and market-focused economic analysis. American exceptionalism in employment contract may illustrate this point, because it touches on the indirect employer role examined by Laborem Exercens. The master-servant analogy upon which 'at will' employment persists is an anachronism among developed nations. It is sustained domestically through a persistent ideology that asserts American competitiveness is necessarily grounded in exceptional degrees of managerial prerogative. But the comparative economic data on competitiveness in value-added manufacturing suggests otherwise in respect to both competitive necessity and ideological merit. To the first point, the postwar success of Germany and Japan indicate just cause and formalized 
employee participation may well have been necessary preconditions for their sustained competitive success, not obstacles. Further, QST/RCST sources indicate employee involvement - the priority of labor over capital - represent the highest aspirations of authenticity as criterion variable. Economic data should be expected to correlate positively and causally support secular employment implications of religious social teaching in modern society.

Montana took a step towards authenticity by just-cause dismissal protections. A similar, simple step can be taken by the National Labor Relations Board by permitting experimentation in employee participation in managerial prerogative based on collective bargaining agreements. This should enhance U.S. competitiveness and end an ideological restraint against workplace inventiveness. ${ }^{25}$ As a sharing in entrepreneurial risk, this step could be readily embraced across the American political spectrum, albeit from differing grounds, while demonstrating the decisive role of the indirect employer, as given in Laborem exercens.

Theological study of workplace relations is an important complement to other fields. First, there is the prophetic critique of the status quo, as Protestant theologian Hauerwas wrote; "The kingdom present in Jesus Christ is the ultimate realism that rightly calls into question vague, secular ideals of freedom, equality, and peace" (Hauerwas, Berkman, \& Cartwright, 2001, p. 389). Second, a theology of the workplace is a witness against jargon in employment issues whether from secular or, all the more, religious institutions. For this, Lonergan's work on authenticity, embedded in a cognitional theory and empirically grounded theological method, offers useful and deployable insights, as this study has tried to show. Theological investigation into workplace relations may now better serve as a proper empirical complement to management spirituality research.

${ }^{25}$ Japan took this step in July 1946 (Tackney, 2009a). Reduction in CEO compensation ratios would undoubtedly follow, as only the U.S. suffers the extreme ratios being reported. On how these mechanisms moderate excessive executive compensation, see (Tackney, 2009b). 
Figure 1. Authenticity in Employment Relations, Pre-RCST/QST Visualization

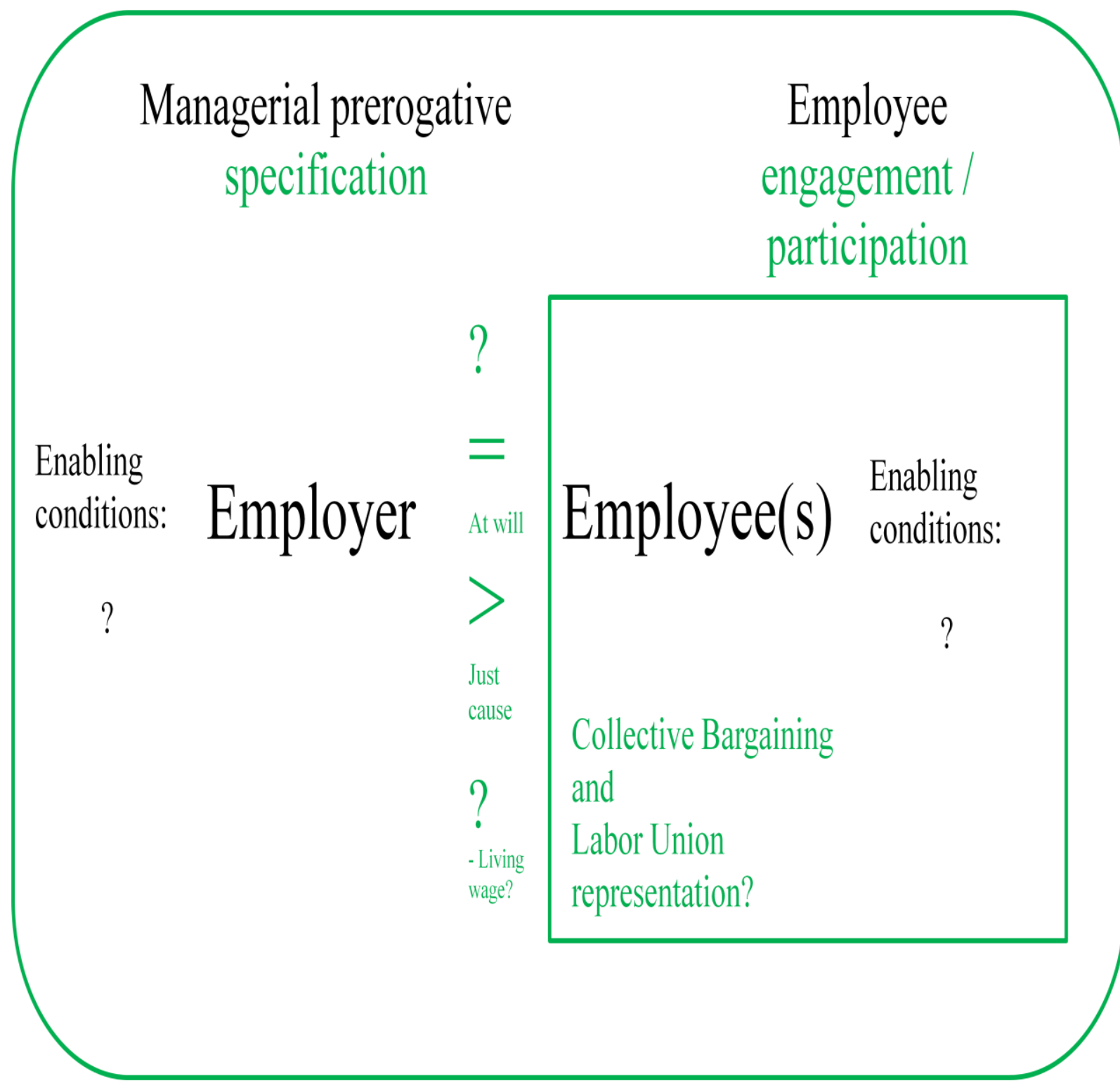

Color code: Black, elements established by review. Green, indeterminate from review, awaiting clarification from theology of the workplace analysis. 
Figure 2. Authenticity in Employment Relations, following RCST/QST analysis

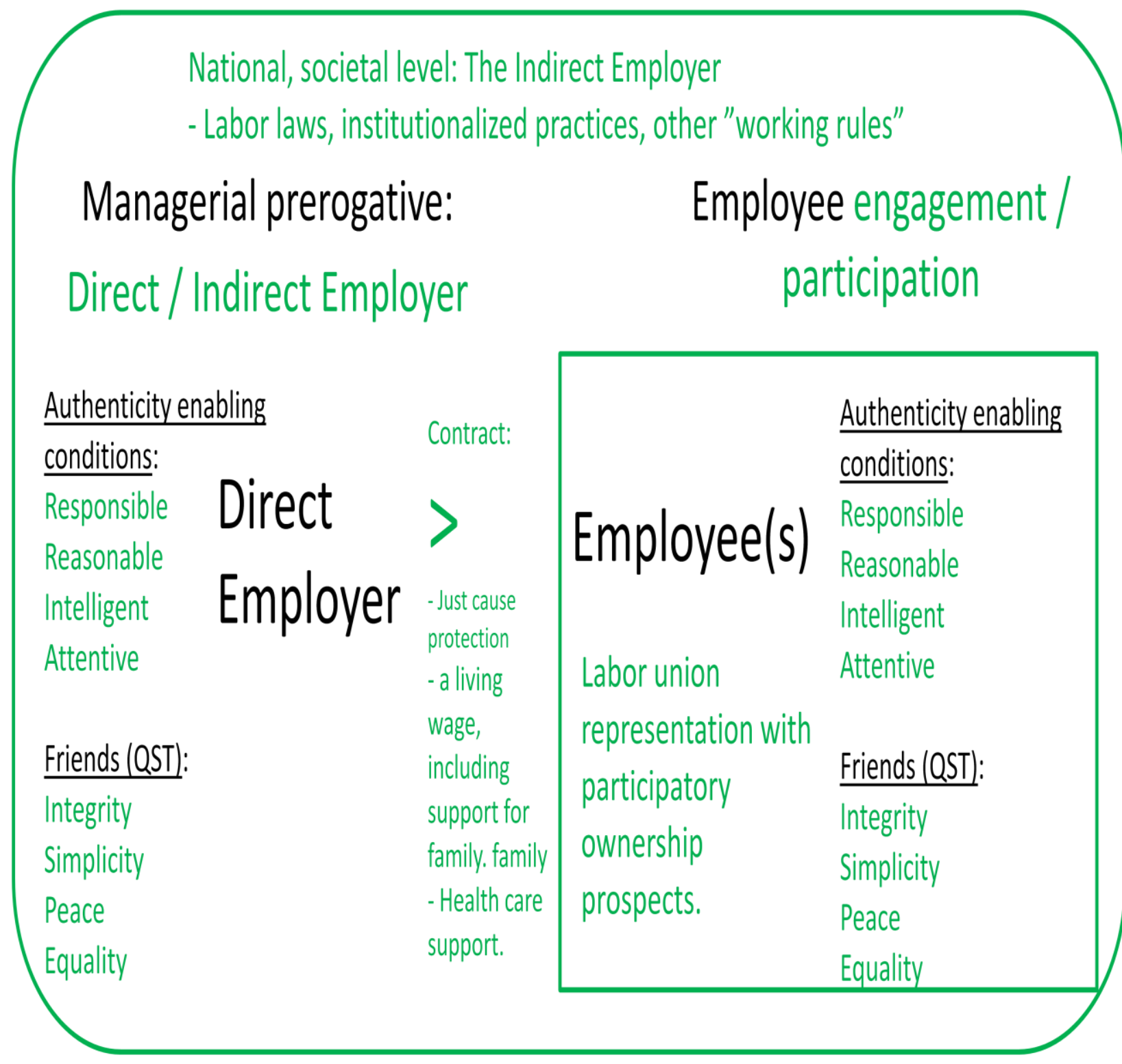

Color code: Black: established by review. Green: established by theology of the workplace analysis.

Goal: An authentic employment relationship in a CSR-compliant, competitive organization calibrated for economic and sustainable success. 


\section{References}

Academy of Management Conference. Program Theme: The Power of Words. Retrieved October 29, 2013 from http://aom.org/annualmeeting/theme/ .

Adorno, T. (1973). The Jargon of Authenticity. Guernsey: Northwestern University Press.

Augustine of Hippo. (1991). The Confessions of St. Augustine. New York: Oxford University Press.

Avolio, B. J., \& Gardner, W. L. (2005). Authentic leadership development: Getting to the roots of positive forms of leadership. The Leadership Quarterly, 16, 315-338.

Bass, B. M. (1985). Leadership and Performance. New York: Free Press.

Befort, S. F., \& Budd, J. W. (2009). Invisible hands, Invisible Objectives. Stanford: Standford University Press.

Benedict XVI, P. (2009). Carita in veritate (Charity in Truth). Vatican City.

Benefiel, M. (2013). The Soul of a Leader. New York: Crossroads.

Blanpain, R. (1998). European Works Councils in Multinational Enterprises

Braman, B. J. (2008). Meaning and Authenticity: Bernard Lonergan and CharlesTtaylor on the Drama of Human Existence. Toronto: University of Toronto Press.

Buber, M. (2000). I and thou. New York: Scribner.

Burns, J. M. (1978). Leadership. New York: Harper \& Row.

Cooper, W. A. (1990). A living faith. an historical and comparative study of quaker beliefs (Second ed.). Richmond: Friends United Press.

Cosden, D. (2004). A Theology of Work: Work and the New Creation. Millton Keynes: Paternoster.

Davison, S. Appendix (2011). Quaker contributions to industrial capitalism. Retrieved December 4, 2013 from http://throughtheflamingsword.files.wordpress.com/2011/09/quakers-capitalismquaker-contributions-to-industrial-capitalism-e28093-a-summary.pdf .

Devonshire House Conference. Foundations of a true social order. 1916. Retrieved, December 4, 2013, from http://throughtheflamingsword.files.wordpress.com/2011/05/foundations-of-atrue-social-order.pdf .

Doran, R. M. Why lonergan? Transcript of a talk given at the launch of the Bernard J. Lonergan Institute of Seton Hall University, November 16, 2006. Retrieved October 3, 2013, from http://www.shu.edu/catholicmission/lonergan/upload/Why_Lonergan_Father_Doran_speech.p df .

Doran, R. M. (2011). What does Bernard Lonergan Mean by 'Conversion'? http://www.lonerganresource.com/pdf/lectures/What\%20Does\%20Bernard\%20Lonergan\%20 Mean\%20by\%20Conversion.pdf

Doran, R. M. (2010). Essays in systematic theology 37: Social grace and the mission of the word. http://www.lonerganresource.com/pdf/books/1/37\%20$\% 20$ Social $\% 20$ Grace $\% 20$ and $\% 20$ the $\% 20$ Mission $\% 20$ of $\% 20$ the $\% 20$ Word.pdf .

Doran, R. M. (2011). Essays in systematic theology 35: Social grace. http://www.lonerganresource.com/pdf/books/1/35\%20-\%20Social\%20Grace.pdf . 
Doran, R. M. (1990). Theology and the Dialectics of History. Toronto: University of Toronto Press.

Dunlop, J. (1958). Industrial Relations Systems. New York: Holt.

Dunlop, J. (1993). Industrial Relations Systems (revised edition). Cambridge: Harvard Business School Press.

Eagly, A. H. (2005). Achieving relational authenticity in leadership: Does gender matter? Leadership Quarterly, 16(474), 495.

Erikson, E. H. (1950). Childhood and society. New York: Norton.

Etzioni, A. (1968). The active society: A theory of societal and political processes. New York: Collier-Macmillan.

Feinman, J. M. (1976). The development of the employment at will rule. The American Journal of Legal History, 20(2), 118-135.

Finn, D. (2006). The moral ecology of markets. Cambridge: Cambridge University Press.

Francis, P. (2013). Evangelii gaudium, on the proclamation of the gospel in today's world. Vatican City: Vatican.

Freeman, R. E., \& Auster, E. R. (2011). Values, authenticity, and responsible leadership. Journal of Business Ethics, 98(1), 15-23.

Gardner, W. L., Cogliser, C. C., Davis, K. M., \& Dickens, M. P. (2011). Authentic leadership: A review of the literature and research agenda The Leadership Quarterly, 22(6), 1120-1145.

George, B. (2004). Authentic Leadership: Rediscovering the Secrets to Creating Lasting Value. New York: Jossey-Bass.

George, W. W. (2013). True north: Discover your authentic leadership. Retrieved November 30, 2013, from http://www.billgeorge.org/files/media/true-north-discovering-your-authenticleadership/GeorgeMonograph.pdf .

Giacalone, R. A., \& Jurkiewicz, C. E. (2003). Handbook of Workplace Spirituality and Organizational Performance. London: M.E. Sharpe.

Golomb, J. (1995). In Search of Authenticity: From Kierkegaard to Camus. New York: Routledge.

Greenleaf, R. (2002). Servant leadership: A journey into the nature of legitimate power and greatness. New York: Paulist Press.

Greenleaf, R. K. (2003). In Beazley H. (Ed.), The servant-leader within: A transformative path. Mahwah: Paulist Press.

Guthey, E., \& Jackson, B. (2005). CEO portraits and the authenticity paradox. Journal of Management Studies, 42(5), 1058.

Hamilton, E., \& Cairns, H. (Eds.). (1961). The collected dialogues of Plato, including the letters. Princeton: Princeton University Press.

Hauerwas, S., Berkman, J., \& Cartwright, M. (2001). The Hauerwas reader. Durham: Duke University Press. 
Jagacinski, R. J., \& Flach, J. M. (2003). Control theory for humans: Quantitative approaches to modeling performance. Mahwah: Lawrence Erlbaum Associates.

John Paul II, P. (1981). Laborem exercens (On Human Work). Vatican City.

John XXIII, P. (1961). Mater et magistra (Mother and Teacher). Vatical City.

John XXIII, P. (1963). Pacem in terries (Peace on Earth). Vatican City.

Jones, R. M. (1911). The Quakers of the American colonies. London: Macmillan.

Kaufman, B. E., \& Hotchkiss, J. L. (1997). The economics of labor markets [null] (Fifth ed.). Orlando: Dryden Press.

Kaufman, B. E. (2004). The global evolution of industrial relations. Geneva: International Labour Office.

Kettler, D., \& Tackney, C.,T. (1997). Light from a dead sun: The Japanese lifetime employment system and Weimar labor law. Comparative Labour Law and Policy, 19(1)

Kierkegaard, S. (2007). Kierkegaard's journals and notebooks: journals AA - DD. Princetom: Princeton University Press.

King, C. B. (2011). Finding the mind: Pedagogy for verifying cognitional theory. Lanham: University Press of America.

Leo XIII, P. (1891). Rerum novarum (Rights and Duties of Capital and Labor). Vatican City.

Leroy, H., Anseel, F., Gardner, W. L., \& Sels, L. (2012). Authentic leadership, authentic folloership, basic need satisfaction, and work-role performance: A cross-level study. Journal of Management, 20(10), 1-21.

Lonergan, B. J. F. (1971). Method in theology. New York: Herder and Herder 1973 Edition as available in, with citations from, Amazon Kindle format.

Lonergan, B. J. F. (1992). Insight. Toronto: University of Toronto Press.

Lonergan, B. J. F. (1998). For a new political economy. Toronto: University of Toronto Press.

Lonergan, B. J.F. (1988). Cognitional structure.. In, Frederik E. Crowe and Robert M. Doran (Eds.), Collection. Pp. 205-221.Toronto: University of Toronto Press.

Lonergan, B.J.F. (1999). Macroeconomic dynamics: An essay in circulation analysis. Toronto: University of Toronto Press.

Lowney, C. (2003). Heroic leadership: Best practices from a 450-year-old company that changed the world. Chicago: Loyola University Press.

Management and Spirituality Division.Domain statement, management and spirituality division, academy of management. Retrieved September 13, 2013, from http://aom.org/Divisions-andInterest-Groups/Academy-of-Management-Division---Interest-Group-DomainStatements.aspx\#msr.

Martin, S. L. (2008). Healing and creativity in economic ethics. New York: University Press of America.

Marx, K. (1970). Critique of the Gotha programme. Moscow: Progress Publishers.

Maslow, A. H. (1968). Toward a psychology of being. New York: John Wiley \& Sons.

Melchin, K. (1988). History, ethics, and emergent probability. Lanham: University Press of America. 
National Conference of State Legislators. The at-will presumption and exceptions to the rule. Retrieved November 21, 2013, from http://www.ncsl.org/issues-research/labor/at-willemployment-overview.aspx .

Northouse, P. G. (2013). Leadership: Theory and practice (Sixth ed.). Los Angeles: Sage.

O'Connell, R. J. (1989). St. Augustine's Confessions: The odyssey of soul. New York: Fordham University Press.

Oppenheimer, M. (2012, June 22, 2012). For Duquesne professors, a union fights that transcends religion. The New York Times.

Paul VI, P. (1965). Gaudium et spes (The Pastoral Constitution on the Church in the Modern World). Vatican City.

Pitchford, E., George K. (2005). An examination of the at-will doctrine. Library Worklife, 2(8) .

Pius XI, P. (1931). Quadragesimo anno (On the $40^{\text {th }}$ Year). Vatican City.

Pontifical Council for Justice and Peace. (2005). Compendium of the social doctrine of the church. Vatican City: Vatican.

Quaker Information Center. Distribution of Quakers in the world. Retrieved, 2013, from http://www.quakerinfo.org/resources/statistics .

Quakers in Britain (2013). How should we best be a supportive and effective employer? Retrieved December 4, 2013 from http://www.quaker.org.uk/how-should-we-best-besupportive-and-effective-employer .

Richardson, W. J. (2003). Heidegger: Through phenomenology to thought. New York: Fordham University Press.

Rogers, J., \& Streeck, W. (1995). Works councils. consultation, representation, and cooperation in industrial relations. New York: University of Chicago Press.

St. Amour, P. (2002). Kierkegaard's retrieval of the existential subject. Method: Journal of Lonergan Studies, 20, 87.

Streeck, W. (1995). Works councils in Western Europe: From consultation to participation. (pp. 313-348). New York: The University of Chicago Press.

Sullivan, S., \& Tumulty, K. (2013, November 24, 2013). Liz Cheney's campaign challenge, family strife 'bruising' Wyoming Republicans. The Washington Post

Tackney, C. T. (2012). A theology of the workplace: Adaptive appropriation in post-world war II Japanese labor law and the roman catholic social question. Theoforum, 43, 107-134.

Tackney, C. T. (1995). Institutionalization of the lifetime employment system: A case study of changing employment practices in a Japanese factory. University of Wisconsin-Madison. (UMI 9608158).

Tackney, C. T. \& Sato, T. (2012). Lifetime employment and the Japanese supreme court: The "discourse of justness" in support of employee protection and managerial participation and the role of cultural cognition for comparative employment relations. Academy of Management Conference, Management History Division, Boston. 
Tackney, C.T. (2001). The modes of social relation in Japanese management practice. In C. Cooper L., S. Cartwright \& P. C. Earley (Eds.), The international handbook of organizational culture and climate (pp. 377-390). London: John Wiley \& Sons.

Tackney, C.T. (2009a). "Ye shall know them by their fruits": American workplace evangelization and the continental European jurisprudence origins of Japanese management practice. Journal of Management History, 15(2), 178-197.

Tackney, C.T. (2009b). Yes, the U.S. auto industry can - if the U.S. congress and Obama administration learn a lesson from Japan. Journal of Employee Rights and Responsibility, 21, 163-164.

Taylor, C. (1992). The ethics of authenticity. Cambridge: Harvard University Press.

Terry, R. W. (1993). Authentic leadership: Courage in action. New York: Jossey-Bass.

The Quakers and Business Group. (2000). Good business. ethics at work. London: The Quakers and Business Group.

Trilling, L. (1971). Sincerity and authenticity. Cambridge: Harvard University Press.

Union, T. C. o.,the European. (1994). Council directive 94/45/EC of 22 September 1994 on the establishment of a European works council or a procedure in community-scale undertakings and community-scale groups of undertakings for the purposes of informing and consulting employees.

Volf, M. (2001). Work in the spirit: Toward a theology of work. Eugene: Wipf and Stock. Walumbwa, F. O., Avolio, B. J., Gardner, W. L., Wernsing, T. S., \& Peterson, S. J. (2008). Authentic leadership: Development and validation of a theory-based measure. Journal of Management, 34(1), 89-126.

Walumbwa, F. O., Wang, P., Wanh, H., Schaubroeck, J., \& Avolio, B. J. (2010). Psychological processes linking authentic leadership to follower behaviors. The Leadership Quarterly, 21(5), 901-914.

White \& Case Law Firm. (September 2011). Global HR hot Topic-September 2011: Employment termination and reductions-in-force outside the United States, part 1. Retrieved November 21, 2013, from http://www.whitecase.com/hrhottopic-0911/\#.Uo4CJMRwrmc .

Windsor, D. B. (1980). The Quaker enterprise: Friends in business. London: Frederik Muller Limited.

Wood, H. G. (1877). A Treatise on the law of master and servant. Albany: J.D. Parsons. 